\title{
ADVOKATO PROFESIJA: PRIEŠTARINGAS JOS POBŪDIS IR KONTROLE
}

\author{
Giedrè Lastauskienè \\ Vilniaus universiteto Teisès fakulteto \\ Viešosios teisès katedros docentè \\ Saulètekio al. 9, I rūmai, LT-10222 Vilnius \\ Telefonas (+370 5) 2366175 \\ Elektroninis paštas Giedre.Lastauskiene@tf.vu.lt
}

Pateikta 2013 m. gruodžio 19 d., parengta spausdinti 2014 m. sausio 3 d.

doi:10.13165/JUR-13-20-4-11

\section{İvadas}

Didžioji dalis Teisès fakulteto pirmo kurso studentų teigia po studijų norị būti advokatais. I klausimą - kodèl, jie dažniausia neturi konkretaus atsakymo. Bet ne vienas iš ju akcentuoja, kad geras advokatas gali padėti žmonėms pasiekti teisingumą.

Be jokių abejonių, advokatas - tai viena iš įdomiausių, seniausių ir svarbiausių teisiniu profesijų. Visi supranta, kad be advokato pagalbos dažniausiai neįmanoma efektyviai išspręsti iškilusių teisinių problemų. Ir jau nè kalbos negali būti, kad apsieitum be advokato, jeigu esi priverstas kreiptis ị teismą arba jeigu kitų asmenų esi pašauktas būti teisme atsakovu ar kitokiu teisminio proceso dalyviu. Neabejojama, kad geras advokatas - didžiulè vertybè ir kad tokị turèdamas (su juo tardamasis) gali gyventi žymiai saugiau ir ramiau.

Lietuvos advokatūra nuo Nepriklausomybès atkūrimo yra patyrusi didžiulius kiekybinius ir kokybinius pokyčius. Užtektų nurodyti, kad advokatų skaičius Lietuvoje nuo 490 advokatų 1995 metais išaugo daugiau negu tris kartus - iki 1888 advokatų 2013 m. 
sausio $1 \mathrm{~d}$. duomenimis ${ }^{1}$. Keitèsi advokatų veiklos organizavimo teisinis reguliavimas (2013 m. rugsèjo $1 \mathrm{~d}$. buvo paskelbti naujausi Advokatūros ịstatymo pakeitimai), kito išsilavinimo ir kitokie reikalavimai advokato veikla siekiantiems užsiimti asmenims (paskutiniais įstatymo pakeitimais šie reikalavimai prilyginti teisèjams ir prokurorams keliamiems reikalavimams) bei Lietuvos advokatūros darbo principai, vyko daugybė kitokių šiai profesijai svarbių pokyčių. Tačiau bene svarbiausia, kad tokiu trumpu laikotarpiu taip ženkliai išaugus advokatų skaičiui, vis labiau ėmė ryškèti advokatų bendruomenès profesinių žinių, intelektualumo, uždarbio ir kiti skirtumai, kad objektyviai kyla prielaidos kalbėti apie tai, ar apskritai galimas koks nors vienas profesinis etalonas, su kuriuo identifikuoja save Lietuvos advokatai, ir kas turètų būti laikomas atsakingas už šios teisinės profesijos atstovų atitiktị kokybiniams kriterijams ir advokato profesijos prestižo palaikymą.

Aptariant, koks yra rašančiųjų advokatų profesijos klausimais įdirbis, yra akivaiz$\mathrm{du}$, kad, nepaisant tų pačių advokato profesijos istorinių šaknų, kiekvienoje valstybèje dèl ganėtinai ryškaus šios profesijos lokalumo daugiausia dėmesio skiriama būtent tos valstybès advokatų veiklos analizei ${ }^{2}$, ir tai yra suprantama. Susipažinus su viešai skelbiamomis Lietuvos autorių publikacijomis, pažymėtina, kad dažniausiai analizuojama advokato kaip teisinio proceso dalyvio veikla ${ }^{3}$, o fundamentalesnių darbų, žvelgiant i šią profesiją platesniu ir analitiškesniu žvilgsniu, tikrai galètų būti daugiau ${ }^{4}$. Advokatų lěšomis leidžiamame žurnale „Lietuvos advokatūra“ taip pat rašoma ịvairiais advokatūrai svarbiais klausimais - bet dẻl specializuoto žurnalo pobūdžio, dẻl pačių publikacijų turinio ir tikslų, dèl jo platinimo tvarkos šios publikacijos pasiekia ne itin didelị žmonių, besidominčių bendraisiais teisès klausimais, ratą (apskritai visos advokatūroje vykstančios ,,vidinès“ diskusijos yra perdèm fragmentiškos ir paviršutiniškos, neišeinančios iš advokatų bendruomenès ribų, ir vien dèl to - nepakankamos). İsiklausius ị pačių advokatų viešoje erdvèje keliamus klausimus, pradeda atrodyti, kad pagrindine problema advokatūra laiko nuolatinị valstybès vėlavimą atsiskaityti už valstybès garantuojamos teisinès pagalbos suteikimą (be abejo, tai yra problema, bet vargu ar advokatūrai esminè). Apibendrinus pažymėtina, kad tyrimuose ir publikacijose advokatūra yra analizuo-

1 Advokatų tarybos veiklos ataskaita. 2012 m. balandžio 20 d. -2013 m. balandžio 12 d.

2 Lietuvai įstojus ị Europos Sajungą objektyviai kyla klausimai dèl Europos Sajungos advokatų užsiimti šia veikla Lietuvoje ir Lietuvos advokatų galimybe teikti paslaugas kitose Europos Sajungos valstybėse. Žr. Vègèle, I. Laisvas advokatų judėjimas pagal Europos Bendrijos teisę. Jurisprudencija. 2008, 3 (105): 47-53.

3 Žalènienè, I. Atstovavimas civiliniame procese (teoriniai ir praktiniai aspektai). Daktaro disertacija. Socialiniai mokslai, teise (01S). Vilnius: Mykolo Romerio universitetas, 2006; Bartkus, G. Advokatų profesinè bendrija - juridinio asmens požymiai. Lietuvos advokatūra. 2007, 2. Internetinèje erdvèje galima susipažinti su A. Smaliuko, A. Brazauskienès, I. Krolienès, R. Beržanskienès ir kitų advokatų pranešimais, aktualiais advokatūrai klausimais: <http://www.ljaa.org/sekminga-konferencija-advokatu-veiklosnaujoviu-klausimais.j?id=348>.

4 Galètų būti išskirti (chronologiškai) tokie darbai: Balnienè, E. Advokatūros atsiradimas ir raida Lietuvoje. Daktaro disertacija. Socialiniai mokslai, teisė (01S). Vilnius: Vilniaus universiteto Teisès fakultetas, 2007; Gumbis, J.; Kūris, E. Advokatai. Lietuvos teisinès institucijos. Vilnius: VI Registru centras, 2011; Krolienè, I. Teisinès pagalbos kokybès vertinimo kriterijai. Lietuvos advokatūra. 2011, 1-2, 3; Drakšas, R. Advokatas: veiklos pagrindai ir problemos. Monografija. Vilnius: Justitia, 2012. 
jama kaip viena iš teisinių institucijų, apibūdinant jos istorines ištakas, formalius reikalavimus asmenims, siekiantiems užsiimti šia veikla, advokato veiklos organizacines ir procesines formas bei principus ir pan. O tyrimų, susijusių su advokatui kylančiomis etinėmis-dorovinėmis dilemomis, advokatūros bendruomenès kokybès patikra ir šios bendruomenès ,išsivalymo“ perspektyvomis ir skirtų plačiai auditorijai, apskritai beveik nėra. Kaip nèra ir publikacijų apie advokato profesijos sampratos pokyčius, kurie vis ryškèja, - panašu, kad kuriamos prielaidos advokatą vis dažniau vertinti ne kaip teisejjo ir prokuroro partnerị ir bendradarbị, o pirmiausia kaip mokamas teisines paslaugas teikiantị ir visomis priemonėmis pelno siekiantị asmenị (ịdomu tai, kad tokias prielaidas formuoja Lietuvos Aukščiausiasis Teismas).

Todèl šio straipsnio tyrimo objektu pasirinkta advokato profesijos vidinio prieštaringumo analizè, atsižvelgiant ị kitas valstybès kontroliuojamas teisines profesijas ir siekiant išsiaiškinti, ar galime identifikuoti Lietuvos advokatų privalomą veiklos etaloną (standartą) ir ar šiuo metu egzistuojančios advokatų veiklos kontrolès formos yra pakankamos, kad advokato profesija užsiimtų tik aukštus elgesio reikalavimus atitinantys asmenys. Šiuo straipsniu taip pat stengiamasi atkreipti dėmesi i j jau nurodytus advokato profesijos sampratos pokyčius ir suaktyvinti diskusiją tarp įvairių teisinių profesijų atstovų, keičiantis tarpusavyje nuomonėmis apie kiekvienos iš jų galimybes, problemas, reiškiant požiūrị, kokie lūkesčiai yra puoselèjami dèl šių profesijų bendradarbiavimo, sprendžiant teisinius ginčus.

Analizei atlikti pasitelktas lyginimas, analizè, sisteminimas, istorinès advokatų veiklos reguliavimo raidos prisiminimas - priemonès, kurios leidžia padaryti apibendrinimus ir, svarbiausia, formuluoti problemas.

\section{Advokato profesijos vidinè priešprieša}

Senovès Romoje, dar iki Imperijos laikmečio, advokatais ${ }^{5}$ vadino besibylinèjančiojo gimines ir draugus, kurie jị lydėdavo ị teismą. Romos Imperijos laikotarpiu šis žodis igijo konkretesnị turinị - juo pradèti vadinti teisme veikiantys gynejjai. Šiandien advokato profesiją laikome savarankiška teisine profesija, pasireiškiančia asmenų, vienoje ar kitoje valstybejje pripažintais advokatais, veikla, teikiant teisinę pagalbą, teisinius patarimus savo klientams ir atstovaujant jiems teismuose, viešosios valdžios institucijose ir prieš kitus viešus ir privačius asmenis ${ }^{6}$.

5 Advokatas - šio žodžio lotyniškas atitikmuo advocatus, o lotyniškasis terminas kildinamas iš žodžio advocatio, reiškiančio prašymą suteikti teisinę pagalbą.

6 Pagal Lietuvos Respublikos advokatūros įstatymą tokios paslaugos yra teisès konsultacijos, teisinę reikšmę turinčių dokumentų rengimas, atstovavimas teisès klausimais, gynyba ir atstovavimas bylų procese, kai šie veiksmai atliekami už atlyginimą, išskyrus atvejus, kai advokatai igyvendina teisę teikti teisines paslaugas nemokamai. Dabartinèje Advokatūros įstatymo redakcijoje advokatų teikiamų paslaugų sąrašas dar labiau išplèstas - nurodyta, kad advokatas gali teikti už atlyginimą bankroto, restruktūrizavimo, turto ir palikimo administratoriaus, lobisto, likvidatoriaus, kuratoriaus, testamento vykdytojo, turto patikètinio, vertejo, kiek tai susiję su advokato teikiamomis teisinėmis paslaugomis, patentinio patikėtinio paslaugas, dirbti visų lygių rinkimų ir referendumo komisijose, būti savivaldybės tarybos nariu, Lietuvos Respub- 
Tiek vertindami advokato profesiją istoriniu, tiek nūdienos kontekstu, susiduriame su paradoksalia situacija - visuomenèje lyg ir pripažịstama didžiulè advokato profesijos svarba, bet tuo pat metu nè viena teisine profesija ar net profesija apskritai nèra tiek pajuokiama, pašiepiama, kritikuojama, o kartais net niekinama. Kaip čia neprisiminus, kad Bernų revoliucijos metu vienas iš pirmujų uždavinių buvo advokatų nužudymas, ir Šekspyro pjesèje „Henrikas VI“ sukilèlis prabyla: „Pirmiausia, ką padarysim, užmušim visus advokatus“. Kritika reiškiama ir teisès autoritetų lūpomis - J. S. Millis rašè, kad „advokatas yra visada pasirengęs savo liežuviu nukryžiuoti teisingumą" pacituoti keletą paplitusių juokelių apie advokatus. Amerikiečiai juokauja: „Žiema buvo tokia šalta, kad net advokatai vaikščiojo susikišę rankas ị savo kišenes“, „Kodèl rykliai nepuola advokatų? Iš profesinio solidarumo“; anglai - „Toks šaltas kaip mielaširdiškumas advokato širdyje“. Ir kaip gi galejjo taip susiklostyti, kad šiuolaikinės visuomenès šmaikštauja apie advokatus būtent tokia, ganètinai sarkastiška ir nedraugiška retorika?

Tikrai nelengva vienareikšmiškai atsakyti, kas lemia toki šios profesijos vertinimą ir advokatams skiriamą ne itin patrauklų vaidmenį bendrakultūriniame kontekste, tačiau tam tikras įžvalgas galètume padaryti. Taip, advokatai visuomeneje yra labai pastebimi, dažnai įtakingi ir žinomi pačiose įvairiausiose socialinėse sferose - nuo politikos (prisiminkime Cicerono kelią - nuo advokato iki žymaus politiko) iki meno mecenavimo (turime tokių pavyzdžių ir šiandieninejje Lietuvoje). Taip, dalis advokatų yra gerai uždirbantys ir kai kurie advokatai mègsta viešojoje erdvejje dalintis įspūdžiais apie savo įspūdingas keliones, gausioje politikų ir dainininkų draugijoje švęstus gimtadienius ar ịsigytus prabangius automobilius. Taip, dalis asmenų pralaimi teisinius ginčus, ir dèl to jų požiūris ị jiems atstovavusius advokatus gali tapti itin kritiškas (ịprastai už advokato paslaugas esi priverstas atsiskaityti bet kokiu, net ir nesėkmès atveju). Tačiau net ir nesigilindami ị visas galimas priežastis, dèl kurių apie advokatų veiksmus ir jų dorovines nuostatas dažnai pasisakoma nepalankiai, galime teigti, kad tokiam advokato profesijos vertinimui labai ịtakos turi ryškus šios profesijos vidinis prieštaringumas, kuris kartais ìvardijamas net terminu ,šizofreniškas“: viena, advokatas yra atlygintinių teisinių paslaugų teikejjas, privalantis siekti, kad jo paslaugos būtų perkamos - nes tik tokiu būdu advokatas gali susikurti sąlygas veiklai vykdyti, apsirūpinti materialiai pats ir aprūpinti savo šeimą; antra, advokatų veikla pasižymi absoliučiu lojalumu savo klientui: advokatas veikia kaip atstovaujamo asmens šešelis, kaip itin artimas klientui žmogus, kartais žinantis apie ji daugiau negu jo artimieji, ir būtent kliento interesai advokatui yra patys svarbiausi; ir trečia, advokatas veikia ne tik kaip pagalbininkas ir paslaugų teikejas, bet ir kaip teisingumo igyvendinimo proceso dalyvis, ir tai sukuria jam specialius reikalavimus ir ịpareigojimus siekti teisingumo, būti padoriam ir nepažeisti tam tikrų pamatinių reikalavimų, kurie šiuolaikinėse valstybės yra keliami teisininkui, teisiniam procesui ir

likos Seimo nutarimu, Respublikos Prezidento dekretu ar Lietuvos Respublikos Vyriausybès nutarimu būti paskirtas komisijos nariu, taip pat padirbti teisès aktų projektų rengimo darbo grupėse (komisijose) ir teikti teisès akto projektui parengti reikalingo tyrimo paslaugas, būti arbitru, tarpininku, taikintoju ar teisès ekspertu, juridinio asmens kolegialaus valdymo ar priežiūros organo nariu. Taigi advokato teikiamų paslaugų spektras (bent jau šiuo metu) yra itin ịvairus ir tikrai daug platesnis negu kitų giminingų teisinių profesijų - notarų ir antstolių.

7 Tokaczyk, R. Etyka prawnicza. Warsszawa, 2007, p. 158. 
teisingumo įgyvendinimui. Taigi advokato veikloje turi būti suderintos trys vertybės: advokato interesas, reiškiantis advokato suinteresuotumą užsiimti šia teisine profesija ir užsidirbti iš to pajamų sau, savo šeimai, savo veiklai; advokato kliento interesas, kurio naudai veikti advokatas ịsipareigoja vos ne besąlygiškai (bent jau po to, kai sudaroma sutartis dèl teisinès pagalbos), ir viešas interesas, suprantamas kaip advokato ịsipareigojimas dorai elgtis teisingumo igyvendinimo procese.

Akivaizdu, kad didžiausią koliziją sukuria būtent advokato pareiga padèti teismui teisingai išspręsti bylą ir jo tiesiog šventa ịvardijama pareiga siekti byloje paties palankiausio savo klientui sprendimo. Tarp šių advokato profesijos dèmenų yra nuolatinè priešprieša. Advokatas, teikiantis paslaugas klientui ir veikiantis kaip jo atstovas ir patarèjas, privalo padaryti viską, kad kliento interesai būtų apginti pačia didžiausia apimtimi, ir tik šis rezultatas yra jo santykio su klientu kokybès matas (o juk būtent šis rezultatas lemia advokato autoritetą, žinomumą, honoraro dydị, klientų skaičių). Konkrečioje situacijoje, siekdamas tokio rezultato, advokatas gali skatinti savo klientą ar kitus asmenis sakyti netiesą (arba nutylèti tiesą); gali teikti ne visus įrodymus, kuriais disponuoja, nes kai kurie įrodymai yra nepalankūs jo klientui; gali vilkinti procesą ar inicijuoti naujus procesus, kai jų skaičius ir bėgantis laikas yra naudingas jo klientui, ir pan. Tačiau advokatas kartu yra ir teisingumo ịgyvendinimo dalyvis. Valstybė suteikia advokatams tam tikras galias ir savotišką imunitetą, siekdama sukurti prielaidas spręsti bylas ir vykdyti teisingumą. Advokatas nėra tiesiog paslaugų teikèjas - kartu su teisèju, prokuroru, antstoliu jis dalyvauja teisingumo igyvendinimo procese. Ir šioje plotmèje advokato įsipareigojimai ir moraliniai imperatyvai yra visiškai kitokie - dažniausiai kaip tik ir uždraudžiantys advokatui atlikti tokius veiksmus, kurie ką tik buvo išvardyti kaip galimi, siekiant klientui naudingo rezultato. Vertinant advokato veiklą šituo aspektu, jis yra ịpareigotas siekti, kad ginčai nebūtų vilkinami ir būtų nagrinèjami ekonomiškai, jis turètų skatinti savo klientą nemeluoti, jis turètų ịrodymus byloje pateikti iš anksto ir visus, nebandydamas kitos proceso šalies priblokšti, išmušti iš vèžių (didelè advokatų dalis siekia rasti galimybę pasielgti būtent tokiu būdu - nes tai kartais gali padèti laimèti bylą).

Sąmoningas (ar nesąmoningas) advokato apsisprendimas suteikti pirmumą kliento interesams dažniausiai dera su paties advokato interesu būti žinomam, populiariam, iš savo veiklos gaunančiam geras pajamas. Esant tokiai situacijai, pačiam advokatui ne visada yra lengva ịvertinti, ar dèl kliento ir savo paties interesų jis neperžengè tam tikrų leistino elgesio ribų - tam yra būtinos išorinès kontrolès sistemos, kurios galètų patikrinti, ar advokatų elgesys yra tinkamas, ar ne, ir jeigu netinkamas - kad ị tokị elgesị būtų sureaguota iš anksto nurodytomis advokatui nepalankiomis poveikio priemonėmis.

\section{Advokatas kaip valstybès kontroliuojamos teisinès profesijos atstovas}

Kalbėdami apie advokato veiklos kontrolę, pirmiausia galvoje turime teisinę kontrolę, kurią realizuoja valstybè: nustatydama teisinius reikalavimus ir tikrindama, ar jų 
laikomasi. Advokato profesija, be jokių abejonių, yra reguliuojama teisės aktais, ir netgi daugiau negu daugelis kitų profesijų. Tiesa, iš pirmo žvilgsnio atrodo, kad advokatas yra laisvos profesijos atstovas: advokatas įsteigia savo darbo vietą, nusprendžia, ar paslaugas teiks pats, ar kooperuosis su kitais advokatais, ar pasitelks ị pagalbą kitus samdomus darbuotojus, o gal apsieis be jų pagalbos, advokatas lyg ir laisvai nustato savo darbo laiką, darbo režimą, pats riboja savo užimtumą. Tačiau tai tik pirmo įspūdžio rezultatas. Turime pasakyti, advokato profesija (kaip ir notaro ar antstolio) yra ganėtinai smarkiai kontroliuojama valstybès, ir tai nulemia objektyvios prielaidos.

Bene svarbiausia priežastis, dẻl kurios valstybė kontroliuoja advokato profesiją, yra ta, kad advokato veikla yra tiesiogiai susijusi su teisingumo igyvendinimu ir teisinès tvarkos valstybèje palaikymu - taigi su viešu ir visai visuomenei svarbiu interesu. Advokatai dalyvauja vykdant teisingumą, atstovaudami savo klientams civilinèse ir administracinèse bylose bei gindami juos baudžiamosiose bylose. Valstybė tradiciškai sukuria ir tiesiogiai iš biudžeto išlaiko baudžiamąsias bylas tiriančias ir valstybės vardu teismuose kaltinimus pateikiančias institucijas. Tačiau kartu valstybė privalo garantuoti, kad asmuo, kuris kaltinamas nusikaltimo padarymu, suvoks jam pareikštus kaltinimus ir sugebès gintis teisinèmis priemonėmis - todèl pradiniame valstybès raidos etape ji įsipareigojo garantuoti, kad kiekvienas žmogus, kuriam yra pateikti įtarimai nusikaltimo padarymu, galès nemokamai pasinaudoti kvalifikuoto advokato pagalba, už kurio paslaugas moka pati valstybė (toks valstybės įsipareigojimas yra konstitucinio lygmens), o šiuolaikinè valstybė plečia įsipareigojimų savo gyventojų atžvilgiu sąrašą ir suteikia nemokamą teisinę pagalbą asmenims, išgyvenantiems turtinį nepriteklių, ne tik baudžiamosiose bylose, bet ir kitose - nagrinèjant civilinius, darbo, administracinius ginčus. Nèra valstybėje teisingumo, jeigu teismuose neužtikrintas principo „Tegul bus išklausyta ir antroji pusé“" igyvendinimas - o tai įmanoma tik tuo atveju, jeigu teisiniame procese rungsis lygiaverčiai dalyviai. Besiginančiam nuo valstybès vardu reiškiamo kaltinimo asmeniui yra būtina teisinè pagalba, kurią suteikia būtent advokatas, taip tapdamas teisingumo igyvendinimo dalyviu. Taigi advokatai, kaip ir notarai ar antstoliai, tam tikrais atvejais veikia kaip valstybès patikètiniai arba bent jau kaip valstybès prisiimtu ịsipareigojimų savo gyventojams vykdytojai. Todẻl valstybei privalu įsitikinti, kad teisę verstis tokia profesine veikla igyja tinkamai pasirengę ir būtinais gebejjimais pasižymintys asmenys.

Lietuvos Respublikos Konstitucinis Teismas, spręsdamas bylas, tiesiogiai įvardijo antstolio ir notaro profesijas valstybès kontroliuojamomis: „antstolio profesija - tai valstybės kontroliuojama profesija, t. y. toks viešaji interesą užtikrinančių funkcijų vykdymas, kai tai daro savarankiška profesine (privačia) veikla besiverčiantys asmenys (už atlygi), o jiems šias funkcijas vykdyti perdavusi valstybė turi kontroliuoti, kaip jos yra vykdomos" ${ }^{\text {“8. } ; ~ „ N o t a r o ~ p r o f e s i j a ~ y r a ~ v a l s t y b e ̀ s ~ k o n t r o l i u o j a m a ~ p r o f e s i j a, ~ t . ~ y . ~ t o k s ~ v i e s ̌ a j i ~}$ interesą užtikrinančių funkcijų - fizinių ir juridinių asmenų subjektinių teisių ir juridinių faktų juridinio ịtvirtinimo, šių asmenų ir valstybès teisètų interesų apsaugos užtikrinimo - vykdymas, kai tai daro savarankiška profesine veikla besiverčiantys asmenys,

8 Lietuvos Respublikos Konstitucinio Teismo 2008 m. sausio 7 d. nutarimas. Valstybès žinios. 2008, Nr. 4-136. 
o jiems šias funkcijas vykdyti perdavusi valstybẻ kontroliuoja, kaip jos vykdomos"9. Advokato veikla Konstitucinio Teismo jurisprudencijoje nèra tiesiogiai taip pavadinta, tačiau tam tikri advokato profesijos kontrolei būdingi požymiai leidžia teigti, kad advokatai taip pat patenka ị valstybès kontroliuojamų profesijų sąrašą.

Sukonkretinant, kaip pasireiškia valstybès kontrolè nurodytoms teisinėms profesijoms Lietuvoje, pasakytina, kad ši kontrolè pirmiausia pasireiškia teisinio reguliavimo nustatymu. Tam tikra valstybès kontrolè prasideda jau tuo metu, kai nustatomas universitetinio teisinio išsilavinimo reikalavimas - teisininkus rengiantys universitetai, priimantys ị tokias studijas ir rengiantys būsimuosius teisininkus, tampa valstybès kontrolès realizavimo pagalbininkais, vykdančiais atranką asmenų, kurie ateityje galės užsiimti advokato (notaro, antstolio) veikla. Visų nurodytų profesijų veiklą Lietuvos įstatymų leidejjas yra sureguliavęs ịstatymo lygmeniu - priimti Notariato, Advokatūros, Antstoliu įstatymai. Valstybès iggaliotas asmuo (teisingumo ministras) yra viešai paskelbęs visų trijų profesinių bendruomenių priimtus statutus - ir tai reiškia, kad valstybe yra patikrinusi ir aprobavusi šių statutų teisėtumą ir patvirtinusi, kad profesinių bendruomenių susikurtos taisyklès dera su valstybės požiūriu. Visų profesijų atžvilgiu valstybè nustato labai tikslius reikalavimus asmenims, siekiantiems verstis ta profesine veikla. Be to, valstybė igaliojo Teisingumo ministeriją atlikti daugybę funkcijų, kurios susijusios su asmenų, pretenduojančių užsiimti tomis profesijomis, žinių ir kitų gebẻjimų patikrinimu. Visų profesijų atstovus valstybė ịpareigojo privalomai draustis civilinės profesinès atsakomybės draudimu, kad būtų garantuotas neteisètais veiksmais padarytos žalos atlyginimas. Valstybè pasiliko sau galimybę vykdyti notarų, antstolių, advokatų veiklos stebèseną ir teisètumo kontrolę - teisingumo ministras gali inicijuoti jiems drausminių bylų iškèlimą.

Nurodytų teisiniu profesijų valstybinio reguliavimo intensyvumas skiriasi, ir akivaizdu, kad advokatų veiklą valstybė kontroliuoja mažiau, paliekant didesnę veikimo laisvę advokatų profesinei bendruomenei. Valstybė nustato antstolių ir notarų skaičių, o advokatų skaičius nèra ribojamas kvotomis (pažymètina, kad nèra reguliuojamas ir antstolio padejjejų bei notaro padejejjų skaičius). Antstolis ir notaras i „,Valstybès žiniose" skelbiamą sąrašą ịrašomas teisingumo ministro ịsakymu, o advokatas ị praktikuojančių advokatų sąrašą įrašoma Lietuvos advokatūros sprendimu - teisingumo ministras apsiriboja tik priesaikos priemimu. Skiriasi ir nurodytų profesijų atstovų darbo organizavimas: teisingumo ministras poịstatyminiais aktais detaliai nustato antstoliu ir notarų darbo organizavimo taisykles - advokatai tokių teisinių nurodymų iš valstybès negauna ir darbo vietos kontrolès klausimai yra palikti pačiai advokatų bendruomenei. Teisingumo ministras yra nustatęs antstoliu ir notarų drausmès bylų nagrinèjimo tvarką, o advokatams tokią tvarką tvirtina Lietuvos advokatūra (teisingumo ministras ją tik paskelbia - tiesa, Advokatūros įstatyme palikta ministrui galimybė atsisakyti ją skelbti, jeigu tvarka prieštarauja teisès aktams).

Trumpas priminimas apie valstybės vykdomą advokatų profesijos kontrolę leidžia padaryti kelias įžvalgas. Pirma, valstybès kontrolè daugiausia išreiškiama teisinių reika-

9 Lietuvos Respublikos Konstitucinis Teismo $2010 \mathrm{~m}$. kovo 22 d. nutarimas. Valstybės žinios. 2010, Nr. 34-1620. 
lavimų advokato profesijai nustatymu, šie reikalavimai yra ịtvirtinti Advokatūros įstatyme ir jị sukonkretinančiuose teisès aktuose ${ }^{10}$, teisiniai reikalavimai yra aiškūs, jų turinio suvokimas nekelia didesnių problemų. Antra, akivaizdu, kad advokatų profesija yra bene mažiausiai varžoma, lyginant su kitomis valstybès kontroliuojamomis teisinėmis profesijomis. Trečia, valstybès kontrolè advokatų profesinio elgesio vertinimo srityje yra minimali - teisingumo ministras tik paskelbia advokatų profesinès etikos kodeksą ir advokatų drausmès bylų nagrinejjimo tvarką ir pagal Advokatūros įstatymą jis turi teisę iškelti advokatui drausmès bylą (tiesa, neteko girdèti, kad tokia teise teisingumo ministras būtų kada nors pasinaudojęs). Todèl galima ịžvelgti, kad didžiają dalị kontrolès, kad advokatais būtų jiems keliamus reikalavimus atitinkantys asmenys, valstybė yra perdavusi advokatų profesiniam susivienijimui - Lietuvos advokatūrai ${ }^{11}$.

\section{Etika kaip advokato veiklos sąlyga}

Kaip jau buvo nurodyta, teisinis advokato veiklos reguliavimas nekelia kokių nors didelių neaiškumų. Taip pat nekelia abejonių ir tai, kad advokatas, kaip ir kiekvienas kitas asmuo, atsako už veikas, kurios atitinka visų rūšių teisės pažeidimų požymius. Tačiau advokato elgesio vertinimas yra siejamas ne tik su jo pareiga laikytis teisinių reikalavimų, bet ir pareiga laikytis advokato etikos reikalavimų. Advokatūros įstatymo 36 straipsnio 1 dalies 3 punkte tiesiogiai daroma nuoroda ị Lietuvos advokatų etikos kodekso nesilaikymą kaip pagrindą nebeleisti advokatauti; 39 straipsnio 1 dalies 1 punkte prioritetine advokato pareiga ịvardijama Advokatų etikos kodekso laikymasis ir pan. Taigi Lietuvos advokatų etikos kodekso pagrindu gali būti priimti išskirtinai reikšmingi advokato atžvilgiu sprendimai - o atsivertę $2005 \mathrm{~m}$. spalio $27 \mathrm{~d}$. Teisingumo ministro įsakymu patvirtintą Lietuvos advokatų etikos kodeksą, randame nedidelès apimties dokumentą, fragmentiškai ir itin abstrakčiai apibūdinantị advokato įsipareigojimus klientams, profesinei bendruomenei, jo pamatinius veikimo principus ${ }^{12}$.

Reikètų pasakyti, kad advokatų etikos kodeksai yra panašaus turinio ir panašios apimties visose Vakarų tradicijos valstybèse, nes jų svarba yra siejama ne su kodekso tekstu. Literatūroje pažymima, kad XVIII amžiuje, itin išaugus advokatų paklausai ir pradèjus didèti advokatų skaičiui, buvo pradèta kreipti daugiau dèmesio ne tik ị teisinị, bet ir moralinį advokatų veiklos reguliavimą, siekiant, kad, augant advokatų skaičiui,

10 Svarbiausiais laikytini šie aktai: Lietuvos Respublikos teisingumo ministro $1999 \mathrm{~m}$. spalio $1 \mathrm{~d}$. įsakymas „Dèl Lietuvos advokatūros statuto patvirtinimo“; Lietuvos Respublikos teisingumo ministro 2005 m. spalio 27 d. ịsakymas „Dèl Lietuvos advokatų etikos kodekso skelbimo“; Lietuvos Respublikos teisingumo ministro $2006 \mathrm{~m}$. birželio $21 \mathrm{~d}$. įsakymas „Dèl advokatų drausmès bylų nagrinejjimo tvarkos skelbimo; Lietuvos Respublikos teisingumo ministro $2007 \mathrm{~m}$. liepos $11 \mathrm{~d}$. ịsakymas „Dèl advokatų drausmès bylų nagrinejjimo tvarkos aprašo skelbimo“. Apie advokatų savivaldos priimtus aktus žr. <http://www.advoco. lt/lt/teisine-informacija/savivaldos-sprendimai.html>.

11 Šiame straipsnyje nèra tiriamų teismų reakcijos ị netinkamą advokatų elgesį, nagrinėjant konkrečias bylas teismuose, kas savo esme taip pat galètų būti laikoma tam tikra kontrolès forma.

12 Nèra lengva ịvertinti Advokatūros įstatymo ir Lietuvos advokatu etikos kodekso tarpusavio santykị, nes, tikslinant reguliavimą, pirmajame daromos nuorodos į antrajji, o antrajame - i pirmaji. Kadangi abiejų teisès aktų reguliavimo sritys susipina, sunku pasakyti, kuris iš jų laikytinas pradiniu, o kuris - blanketiniu. 
ir toliau būtų išlaikytas elitinis šios profesijos pobūdis. O XX a. pasižymèjo tuo, kad buvo pradèti leisti ịvairūs teisinių profesijų etikos kodeksai, taip pat ir advokatų, kurie tapo papildomų reikalavimų rinkiniais, skirtais tų teisinių profesijų atstovams ${ }^{13}$. Etikos kodeksų svarba pasireiškia ne jų turiniu, kažkokiu nuoseklumu ar ypatingu sistemišku$\mathrm{mu}$ - svarbus buvo ir yra pats etikos kodekso buvimo faktas, patvirtinantis, kad asmenys, kuriems jis skirtas, negali apsiriboti teisinių reikalavimų laikymusi ir kad jiems yra privalomi aukštesni elgesio standartai. Teisininkų etikos kodeksų atsiradimas siejamas su noru šviesti teisinę bendruomenę, paaiškinant, koks profesinis elgesys gali būti ne tik teisètas ir neteisètas, bet ir geras ar blogas, padorus ar nepadorus, etiškas ar neetiškas. Reikšmingas tampa pats žinojimas, kad ị nepadorų advokato elgesị bus reaguojama, galbūt net uždraudžiant tokiam asmeniui užsiimti advokato profesine veikla.

Taigi advokatų ịsipareigojimas laikytis etikos kodekso reikalavimų reiškia jo įsipareigojimą veikti etiškai ir padoriai - klientų ir kitų proceso dalyvių, kolegų, viešosios valdžios, advokatų bendruomenès atžvilgiu. Tačiau laikytis šių reikalavimų advokatui yra gerokai sunkiau negu kitų teisinių profesijų atstovams - būtent dèl prieštaringos jo profesijos prigimties. Kaip jau buvo rašyta, savo paslaugomis advokatas turi užsidirbti pajamų, pakankamų tam, kad patenkintų savo asmeninius poreikius ir susikurtų bei finansuotų savo, o dažnai ir kitų, jam padedančių darbuotojų darbo vietų išlaikymą, kad galètų dali jų skirti savo kvalifikacijos kèlimui ir saviugdai, pagaliau - kad galètų susimokèti mokesčius valstybei. Tačiau advokatas kaip vienas iš teisingumo igyvendinimo proceso dalyvių, nors ir nebūdamas valstybès tarnautojas, tampa viešojo intereso atstovu ir bendrojo gério gynèju (Lietuvos advokatų etikos kodekso 1.1 punkte nurodoma, kad Lietuvos advokatai dalyvauja igyvendinant teisingumą, o 1.3 punkte - kad jie privalo nediskredituoti teisingumo idejos). Advokatą saisto ne tik ịpareigojimas teikti tiesiog kokybiškas teisines ir kitokias paslaugas, bet ir didesni padorumo ir elgesio reikalavimai negu kitam asmeniui, taip pat teikiančiam kokias nors atlygintines paslaugas. Advokato išsilavinimo ir kitokie reikalavimai, keliami asmeniui, siekiančiam tapti advokatu, yra skirti tam, kad būtų užtikrintas aukštas advokato paslaugų teikimo lygis. O reikalavimas, kad advokato reputacija būtų nepriekaištinga ir kad savo veikloje jis laikytųsi etikos reikalavimų, turètų užtikrinti, jog greta teisėjo ir prokuroro veiks žmogus, kuriam taip pat keliamas ,ک̌varių rankų“ reikalavimas ${ }^{14}$.

Reikètų pasakyti, kad nurodyta priešprieša (tarp pareigos veikti kliento naudai ir pareigos likti padoriam) yra žinoma, svarstoma ir analizuojama (nors Lietuvoje tokių publikacijų neabejotinai trūksta). I galvą ateina aštri diskusija dẻl advokato veikimo principų, prasidejjusi po žinomo JAV sportininko O. J. Simpsono, apkaltinto itin žiauriai nužudžius savo žmoną N. Brown ir jos pažistamą, su kuriuo ji leido vakarą. Nors

13 Pirmieji teisininkų etikos kodeksai buvo sukurti XX amžiaus pirmoje pusejje (literatūroje nurodoma, kad Ženkliai vėliau negu, pvz., medikų etikos kodeksai): 1908 m. - JAV, 1920 m. - Kanadoje, 1934 m. Brazilijoje. Kalbant apie advokatų etikos kodeksus, tokio pobūdžio reguliavimo pradžia siejama su JAV, kurios Alabamos valstijoje toks pirmasis dokumentas atsirado jau $1887 \mathrm{~m}$.

14 Svarstytinas klausimas, ar visa apimtimi turètų veikti etikos reikalavimai, advokatui teikiant papildomas paslaugas, numatytas keičiant Advokatūros įstatymą: lobisto, bankroto administratoriaus, ịvairių komisijų nario ir pan. 
mokslu paremti įrodymai akivaizdžiai tvirtino faktą, kad Simpsonas yra kaltas dèl šių žmonių mirties, prisiekusieji vienbalsiai pripažino jị nekaltu, ir tokia neịtikètina bylos baigtis buvo siejama su agresyvia ir itin išradinga kaltinamojo advokatų gynyba, kai advokatams pavyko ,,paprastą nužudymo bylą paversti referendumu rasizmo Amerikoje klausimu“15. JAV tiesiog suliepsnojo diskusijos dèl gynybos baudžiamosiose bylose ribų, virtusios tolesne reliatyviai suprantamos tiesos teorijos teisèje plètote. Žinomas JAV teisininkas, Harvardo teisès profesorius A. Derchowitzius, taip pat dalyvavęs Simpsono advokatų ,svajonių komandoje“, vėliau rašè, kad tiesa esanti tik vienas iš baudžiamojo proceso tikslų ir kad ji esanti daug labiau komplikuota sąvoka, negu gali atrodyti iš pirmo žvilgsnio. Derchowitzius siūlo procesą vertinti kaip gladiatorių dvikovą, kurioje vienas laimi, o kitas pralaimi, ir kurioje laikyti tinkamu reikia bet kokị teismo priimtą sprendimą, nepriklausomai nuo šio sprendimo santykio su tiesa. Žymusis advokatas ir teisès profesorius primena, kad dauguma advokatų didžiają dalị laiko atstovauja būtent iš tikrųjų kaltiems klientams, turèdami vieną užduotic - kvestionuoti kaltinimą, formuluojant dèl jo ,pagrịstas abejones“ (angl. reasonable doubts), visomis leistinomis priemonėmis siekiant, kad „tiesa nepaaiškètų“16 .

Tikrai tokie pat klausimai kyla ir Lietuvos advokatams, tačiau, skirtingai negu kitur, Lietuvos advokatai (o ir kiti) šiais klausimais beveik nediskutuoja viešai (išskyrus retas išimtis pačių advokatų leidžiamame žurnale „Lietuvos advokatūra“) - atrodytų, kad jokios vidinès sumaišties nei dẻl savo, nei dẻl kolegų elgesio Lietuvos advokatai apskritai nejaučia. Straipsnio autorei taip pat nėra žinoma, kad advokatų bendruomenès ar kitų asmenų iniciatyva būtų buvę atlikti kokie nors rimtesni visuomenės nuomonès tyrimai, kurie leistų įvertinti, kokius lūkesčius dẻl advokatų veiklos puoselèja Lietuvos gyventojai ir ar tie jų lūkesčiai yra patenkinami. Sunku būtų nurodyti kokias nors analitines-kritines publikacijas, kuriose pasisakoma, kaip elgtis advokatui, suvokus, kad pareiga kuo geriau apginti kliento interesus ir pareiga laikytis etikos reikalavimų suponuoja skirtingus jo elgesio variantus ir kad jis turi kokiu nors būdu nuspręsti, kaip konkrečiai jam reikètų pasielgti. Advokatui svarbu išmokti atpažinti tokias kolizines situacijas, kurios yra dažnos advokato veikloje, ir turèti apgalvotą tokiems atvejams poziciją: ar advokatas gali neteikti teismui ịrodymų, kurie yra reikšmingi bylos išsprendimui, bet nepalankūs jo klientui? Ar advokatas gali meluoti teismui, jeigu tokia pozicija gali padèti apginti kliento interesus? Ar advokatas gali siūlyti klientui sakyti netiesą, jeigu tai yra vienintelè galimybé laimėti bylą? Ar advokatas gali nutylèti tiesą ir pasiūlyti tai padaryti klientui? Ar advokatas gali atsisakyti teikti paslaugas asmeniui, jeigu jo padaryti neteisèti poelgiai kelia advokatui pasibjaurejjimą, atvirai nurodant būtent tokị atsisakymo pagrindą? O gal advokatas turètų meluoti, nurodydamas išgalvotą pagrindą, pvz., teisindamasis dideliu užimtumu? Ar advokatas privalo saugoti kliento suteiktos informacijos konfidencialumą, jeigu informacijos išviešinimas gali padèti užkirsti kelią naujiems nusikaltinimams?

Ne kiekvienas advokatas turi pakankamai vidinès jègos ir stiprumo, kad suveiktų jo vidinè savireguliacija, kuri sustabdytų ji nuo veiksmų, nederančių su bendruoju

15 Zajadło, J., et. al. Fascynujące ścieżki filozofii prawa. Warsszawa, 2008, p. 207.

16 Ibid. 
reikalavimu elgtis padoriai. Valstybė, kaip buvo nurodyta, advokatų veiklos kontrolę vykdo nustatydama jiems teisinius reikalavimus, ir ji tikrai nereaguoja, aiškindamasi, ar advokatas laikosi etikos taisyklių. Todèl pagrindiniu subjektu, privalančiu tai daryti, lieka advokatų profesinis susivienijimas, t. y. Lietuvos advokatūra.

\section{Advokatas kaip laisvos profesijos atstovas ir advokatu bendruomenè}

Lietuvoje asmenys gali veikti kaip advokatai tik tokiu atveju, jeigu jie yra advokatu asociacijos - Lietuvos advokatūros - nariai ${ }^{17}$. Nuo pat Lietuvos nepriklausomybès atkūrimo teisiniame diskurse vis iškildavo klausimas - ar valstybès kontroliuojamų teisinių profesijų atstovai gali veikti, nesijungdami į teisinių profesijų atstovų sajungas (Lietuvos advokatūrą, Lietuvos antstolių rūmus, Lietuvos notarų rūmus). E. Kūris, vertindamas faktą, kad 2004 m. iš pradžių Seimui buvo pateiktas Advokatų ịstatymo projektas, bet ji svarstant Seime jis buvo pavadintas Advokatūros įstatymu, iškelia įdomią minti jo vertinimu, jei pavadinime būtų paliktas žodis „Advokatų“, galèjo atsirasti teisinès prielaidos kalbèti taip pat ir apie advokatūrai nepriklausančius advokatus ${ }^{18}$. Ši diskusija galutinai buvo pabaigta $2008 \mathrm{~m}$. sausio $7 \mathrm{~d}$. Konstitucinio Teismo nutarimu, kuriuo atitinkančiomis Konstituciją buvo pripažintos Antstolių įstatymo nuostatos, įtvirtinančios privalomą antstolių narystę Antstolių rūmuose. Konstitucinis Teismas, patvirtindamas antstolių pareigą jungtis i asociaciją, suformulavo ir doktrininị atsakymą dèl kitų valstybès kontroliuojamų teisinių profesijų atstovų - buvo nuspręsta, kad jų naryste asociacijose yra privaloma ${ }^{19}$.

Advokatūra kaip laisvų advokatų sajunga turètų veikti kaip viena iš svarbiausių institucijų, užtikrinančių, kad advokatams būtų sudarytos tinkamos sąlygos veiklai vykdyti.

17 Pvz., Prancūzijoje veikia net 161 advokatų taryba, $1991 \mathrm{~m}$. dekretu joms patikèta spręsti visus advokatų veiklos klausimus. Visas advokatų tarybas vienija Nacionalinė advokatų taryba, siekianti vienodinti visų advokatų tarybų veiklos principus. Vokietijoje sudarytos 27 regioninès advokatų asociacijos ir viena federalinė asociacija. Žr. Bitinas, A. Advokatūros vieta valstybèje: nepriklausomumo ir autonomijos užtikrinimas. Justicija. 2012, 77: 4-13.

18 Gumbis J.; Kūris, E., supra note 4, p. 578.

19 Lietuvos Respublikos Konstitucinio Teismo 2008 m. sausio 7 d. nutarime nurodyta: „Visuotinai - ne tik Lietuvoje - pripažįstama, kad tokios valstybès kontroliuojamos profesijos kaip antstolio ir kt. (beje, ne vien teisinès profesijos) suponuoja atitinkamos profesijos savireguliaciją ir atitinkamą savivaldos sistemą, kuri apima visą šią profesiją (visus ja besiverčiančius asmenis) ir užtikrina inter alia atstovavimą tai profesijai (ja besiverčiantiems asmenims) esant santykiams su valstybès ir savivaldos institucijomis bei tarptautiniu lygiu, kvalifikacijos tobulinimo organizavimą, vienodus profesinès etikos standartus ir jų laikymosi kontrolę, taip pat kitokią įstatymų reikalaujamą tos profesijos asmenų veiklos kontrolę. Jeigu tokios savireguliacijos ir savivaldos sistemos nebūtų, atitinkamų funkcijų, kurių vykdymą valstybė privalo užtikrinti, perdavimas ị privačias rankas ne tik būtų nepagrịstas tikslingumo atžvilgiu, bet ir galètų būti konstituciškai nepateisinamas. Tikslingumo atžvilgiu nepateisinama, gal ir konstituciškai nepagrịsta, būtų ir tai, kad kurie nors tam tikra valstybès kontroliuojama profesija besiverčiantys asmenys galètų būti „šalia“ minètos profesinès savivaldos sistemos ir ne tik neprisidètų prie jos veikimo, bet ir galètų išvengti atitinkamos profesinès veiklos kontrolès, inter alia kontrolès, ar tie asmenys laikosi vienodų profesinès etikos standartų.“ 
Valstybė suteikia advokatams tam tikrą autonomiją, vykdydama tik tokią kontrolę, kuri yra būtina ir neišvengiama, valstybei vykdant savo įsipareigojimą jos gyventojams, užtikrinti, kad visi teisingumo ịgyvendinimo dalyviai atitiktų tam tikrus jiems keliamus reikalavimus. Rašantieji advokatų veiklos klausimais pabrěžia, kaip svarbu yra apsaugoti advokatus nuo, svarbiausia, valstybès (viešosios valdžios) ir kitokių galimų įtakų: „Advokato veiklos laisve ir nepriklausomumas reiškia, kad advokatas, atlikdamas profesines pareigas, gali ir turi veikti visiškai laisvai, paisydamas tik ịstatymuose ir kituo-

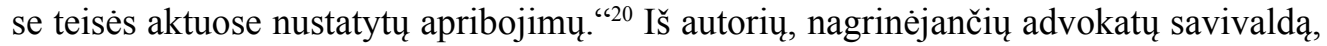
darbų kyla įžvalgos, kad būtent Advokatūra yra laikoma tuo saugiuoju advokatų ,prieglobsčiu“" nuo viešosios valdžios, o galimai ir nuo kitokių įtakų. Straipsnio autorei nėra aišku, kokiais būdais advokatūra saugo advokatą nuo „bet kokių kitų juridinių ar fizinių asmenų poveikio, žiniasklaidos ar politinių partijų ịtakos ${ }^{\text {“"21 }}$, nors tikrai būtų galima sutikti, kad Advokatūra privalètų saugoti jos narius nuo viešosios valdžios tiesioginès įtakos, organizuojant advokatų veiklą ir užtikrinant jiems laisvę nuo išorinio valstybès kišimosi, vykdant advokatui suteiktas funkcijas.

Pagrindinis advokatūros tikslas nekelia abejonių - Advokatūra privalo ịgyvendinti advokatų savivaldą. Tačiau įdomu būtų pasižiūrèti, kokie uždaviniai tokị tikslą konkretina. Susipažinus su Advokatūros įstatais, Advokatūros statutu ${ }^{22}$ ir Advokatūros ịstatymu, akivaizdžiai išsiskiria du itin svarbūs šios sajungos uždaviniai: pirma, advokatūra privalètų veikti kaip visų advokatų interesus telkianti, ginanti, jų nepriklausomumą nuo viešosios valdžios užtikrinanti ir tinkamo advokatams teisinio reguliavimo siekianti institucija; antra, advokatūra turètų veikti kaip organizacija, užtikrinanti, kad ị advokatūrą patektų ir advokato veikla užsiimtų tik tinkamą kvalifikaciją turintys ir griežtus elgesio standartus atitinkantys žmonès. Būtent antrasis uždavinys yra sietinas su profesinio susivienijimo vykdoma advokatų veiklos kontrole profesinès etikos laikymosi srityje, kuris šios publikacijos kontekstu yra įdomiausias. Advokatų savivaldos organai turètu padèti advokatams susivokti, kokio elgesio iš jų yra tikimasi - tiek organizuojant kokybiškus mokymus, tiek ịspejjant netinkamai besielgiančius advokatus ar kitaip reaguojant ị etikos standartų neatitinkantị savo kolegų elgesį. Nes ị šią veiklą nesikišant valstybei, būtent advokatų susivienijimas profesijos pagrindu privalo veikti kaip pagrindinè kontrolès sistema, užtikrinanti, kad advokato profesija užsiimtų aukšto lygio profesionalai, sugebantys derinti atstovavimą savo klientams su padorumu ir specialiais uždaviniais igyvendinant teisingumą.

Lietuvos advokatūra kaip save valdanti institucija veikia ir uždavinių igyvendinimo siekia per savo organus: 1) visuotinị advokatų susirinkimą; 2) Advokatų tarybą; 3) Advokatų garbès teismą; 4) Revizijos komisiją.

Vertinant visuotinio advokatu susirinkimo galimybes, reikia vèl grịžti prie duomenų apie tris kartus išaugusį advokatų skaičių, kuris artēja prie 2000. Taigi i visuotinị susirinkimą ir yra kviečiami visi šie du tūkstančiai. Todèl (ir dèl kitų, subjektyvių

20 Gumbis, J.; Kūris, E., supra note 4.

21 Bitinas, A., supra note 17, 7.

22 Vadovèlyje „Lietuvos teisinės institucijos“ išreikštas kritiškas Lietuvos advokatūros statuto vertinimas. 
priežasčių) visuotinio advokatų susirinkimo reikšmė yra visiškai nebeaiški. Šis organas funkcionuoja kaip ne toje pačioje vietovèje dirbančių kolegų, bendramokslių ir šiaip pažistamų susitikimo ir pabendravimo forma, o ne vieta, kurioje vyktų produktyvus darbas. Visuotiniame advokatų susirinkime nėra iš tikrujų sprendžiami Lietuvos advokatūrai svarbūs klausimai. Vertinant oficialiąą susirinkimo pusę, susidaro įspūdis, kad susirinkimai vyksta arba kaip chaotiškas ir mažai naudos duodantis individualių nuomonių išsakymas, arba kaip formalus ir neprobleminis svarstomų savivaldos dokumentų pristatymas bei mechaninis jų patvirtinimas. Nors kiekvienam, susimąstančiam apie Advokatūros veiklos kokybę, yra aišku, kad tokie visuotiniai susirinkimai kaip didelès organizacijos savivaldos forma yra atgyvenusi ir neefektyvi, nepastebėtina, kad būtų galvojama bent ką nors šiuo klausimu keisti (galvoti apie regioninių savivaldos organų sukūrimą, apie galimybę, kad ị susirinkimą rinktųsi tam tikru būdu išrinkti atstovai arba bent jau mąstyti apie kitoki šių susirinkimų darbo organizavimą: pvz., kodèl advokatai negalètų gauti visų susirinkime svarstomų dokumentų projektus iš anksto ir taip igyti galimybę iš anksto teikti dèl jų savo pastabas, o gal net balsuoti?). Svarstymai, kaip keisti šiuo metu periodiškai kartojamą tiesiogiai realizuojamos savivaldos imitaciją, organizuojant visuotinius susirinkimus, yra būtini, nes advokatų skaičius, tikètina, ir toliau augs, o tai gali lemti dar didesnị chaosą ir dar mažesnị šio organo veiklos efektyvumą ${ }^{23}$.

Visuotiniam advokatų susirinkimui veikiant tokiu būdu, kokiu jis veikia šiuo metu, advokatų veiklos kontrolès formas belieka sieti su Advokatų tarybos, kaip kontrolès strategijos formuotojos, ir Garbès teismo, kaip advokatų drausmės bylas tiriančio organo, veikla.

Advokatų tarybos stiprinimas galètų būti tinkama priemonè, siekiant organizuoti advokatų veiklos priežiūrą, kontrolę, koordinavimą ir pagalbą žmonėms, turintiems šią teisinę profesiją. Pasisakant dėl jos veiklos, organizuojant advokatų ugdymą (žodis mokymas gal ir ne itin tiktų tokiame kontekste, nes vargu ar galima išmokyti padorumo) advokatų etikos klausimais, pažymėtina, kad tokia advokatų savivaldos organų veikla yra labai neryški. Jau buvo nurodyta, kad negirdèti apie reprezentatyvius advokatų veiklos ir padorumo vertinimo sociologinius tyrimus. Straipsnio autorei nėra žinoma, kad būtų rengiami šiais klausimais seminarai ar kitokie užsiėmimai (tiesa, apie advokato etiką yra užsimenama ịvadiniuose seminaruose, skirtuose ,naujiems“ advokatų padèjèjams, šios temos taip pat yra įtraukiamos ị advokato egzamino klausimus). Panašu, kad pagrindine Lietuvos advokatūros kaip profesinès bendruomenės požiūrio išsakymo forma lieka Garbės teismo sprendimai (Lietuvos advokatūros poziciją išreiškia ir oficialių jos atstovų vieši pasisakymai, tačiau vargu ar galètume juos vadinti advokatų veiklos kontrolès formomis).

Susipažinus su Lietuvos advokatūros advokatų garbės teismo laikotarpio nuo $2012 \mathrm{~m}$. balandžio 20 d. iki 2013 m. balandžio12 d. ataskaita, aiškėja, kad per ši laikotarpi Advokatų garbės teismas išnagrinèjo 107 drausmès bylas, iš jų 84 buvo iškeltos dẻ įmokų bendriems advokatūros reikalams nemokejjimo, advokato profesinès civilinès atsako-

232013 m. sausio 1 d. praktikuojančių advokatų sąraše buvo 1888 advokatų, advokatų padẻjëjų (t. y. būsimujų advokatų) -827 . 
mybės privalomojo draudimo poliso ir (ar) sveikatos pažymos nepateikimo. Pateikiami duomenys apie tai, kad vienas advokatas ir vienas advokato padejjèjas buvo pašalinti iš profesinès korporacijos.

Be jokių abejonių, yra blogai, jeigu advokatas nemoka ịnašų savo bendruomenei ar nepateikia civilinès atsakomybès draudimo polisų, ir ị tokị jų elgesị tikrai reikia reaguoti. Bet tai savo esme reiškia tiesiog teisinių reikalavimų nesilaikymą, ir tikrai yra nesudètinga tokius atvejus ịvertinti. Tačiau advokatų veikloje yra daug rimtesnių ir sunkiau sprendžiamų problemų - nors Advokatų garbės teismo ataskaitos paskelbtos viešai, neatrodo, kad ị drausminių bylų nagrinejjimo arba bent jau Lietuvos advokatūros organų pozicijos išsakymo lygmenį būtų persikèlusios diskusijos dèl advokatų padorumo ribų, apie kurias rašoma šiame straipsnyje ir apie kurias kalba visuomenè. Sveikintinas sprendimas išspausdinti „Lietuvos advokatūroje“ Advokatų etikos taisykles, suformuluotas 1928-1933 m. Advokatų tarybos ir Vyriausiojo tribunolo sprendimais ${ }^{24}$. Sužinome, kad advokatui sakyti, kad gydytojo išduotas liudijimas yra „lengvai gautas“, reiškia „tvirtinti, kad liudijimo turinys neatitinka tikrenybès“ < ..>, ir toks advokato pareiškimas „,be abejo, turi skaitytis įžeidžiančiu ir vertas papeikimo“; „Kalbètis advokatui su liudytojais apie bylą ne tik neleistina, bet ir draudžiama, nes leidus kalbẻtis būtu plati dirva ịvairiems nesąžiningumams, o doram advokatui tankia grestų pavojus šantažo, tvirtinant, kad advokatas mokino meluoti“; , „Vyriausioji advokatų darbuotès sąlyga - visuomenès pasitikejjimas. Kur nèr tos sąlygos, negali būti advokatų“; „Kiekvienas advokatas, pastebejjęs savo kolegos etikos netinkamą elgesị, privalo apie tai pranešti Advokatų tarybai““ ir pan. Be abejo, nereiketų šių citatų pagrindu pradèti romantizuoti praejusių laikų advokatus, bet akivaizdu, kad advokato veikla buvo vertinama ganètinai smulkmeniškai, darant nuorodas į advokato etiką, dorą, visuomenès pasitikèjimą juo, ir užtenka susipažinti vien su žurnale paskelbtomis taisyklemmis, kad galètum padaryti išvadą - daugelis šių taisyklių šių dienų advokatams sukeltų šypseną.

Advokato veiklos principai šiuolaikinejje visuomenejje, pasižyminčioje didžiule socialine dinamika, aštria advokatų konkurencija, yra pakitę. Net ir patys advokatai, vertindami kolegų elgesị, kartais vartoja sąvoką - „naujos kartos advokatas“, dažniausiai turèdami galvoje išskirtinį agresyvumą (net ir kolegų atžvilgiu), meistrišką manipuliavimą teisinėmis priemonėmis, ne visada siekiant teisinių, kartais neteisinių ar net antiteisinių rezultatų, didelį aktyvumą, „užspaudžiant“ priešingą šalị ị kampą, ir pan. Veikiama laikantis principo „Mano kliento tikslas yra man aukščiausia vertybé“. Pavyzdys: vienos iš šalių advokatas kiekvieną savo pasisakymą teismo posėdžio metu pradeda nuo teiginio, kad priešingos šalies advokatas nesuvokia ginčo esmès, klaidina teismą ir netinkamai pataria savo klientui. Kai toks teiginys pakartojamas daugybę kartų, tai, be abejo, trikdo ir nepadeda susikaupti ties ginčo esme - tuo palengvinant darbą procese tokią retoriką naudojančiam advokatui. Ar toks advokato elgesys laikytinas etišku? Ar tinka advokatui dalyvauti bulvarinėse (apkalbų lygmens) laidose ir ịvairiausiuose šokių, dainų ir kitokių išmonių projektuose? Ar galètų dirbti prokuroru asmuo, kurio iššau-

24 Advokatų etikos dėsniai pagal Advokatų tarybos ir Vyriausiojo tribunolo nutarimus (parengè E. Rusinas).

Lietuvos advokatūra. 2011, 4. 
kiančios nuotraukos skelbiamos ịvairiausiose visuomenè informavimo priemonėse - o jeigu negalètų, tai kodėl taip besielgiančiam advokatui neprimenama, kad toks elgesys negali būti laikomas atitinkančiu Etikos kodekso reikalavimą saugoti profesinę garbę, orumą ir nediskredituoti advokato vardo ir duotos priesaikos? Ar galètų kitas advokatas dèl kokio nors ne itin tinkamo savo kolegos elgesio kreiptis į Advokatų tarybą ir tikètis principingo (o ne formalaus) tokio kolegos elgesio įvertinimo? Pagaliau, ar Advokatu taryba nemato viešoje erdvejje pasirodančios informacijos ir ar neturètų i ją reaguoti savo iniciatyva? Lietuvos advokatūros organų pozicija dèl tokių ir panašių situacijų nėra žinoma, ir net nèra aišku, ar tokią poziciją šie organai apskritai turi.

O pozicijos turejjimas yra būtinas, nes neatsakytų klausimų advokatų profesinei bendruomenei kils vis daugiau. Tokią ižvalgą daryti verčia keli pastarujų dienų faktai. Viena, Lietuvos Aukščiausiasis Teismas, spręsdamas konkrečią bylą dẻl advokato reikalavimo klientui sumokèti jam ịsiskolinimą už suteiktas teisines paslaugas, $2013 \mathrm{~m}$. spalio 7 d. nutartimi civilineje byloje Nr.3K-7-395/2013 nusprendè šią bylą sustabdyti ir kreiptis ị Europos Sajungos Teisingumo Teismą su prašymu priimti prejudicinị sprendimą, išaiškinant, ar fizinis asmuo, kuris gauna teisines paslaugas pagal atlygintines teisinių paslaugų sutartis, sudarytas su advokatu, ir šios teisinès paslaugos teikiamos bylose, kurios galbūt susijusios su fizinio asmens asmeniniais interesais, pripažintinas vartotoju Europos Sajungos vartotojų teisių apsaugos prasme ir ar advokatas, teikiantis prieš tai nurodytu būdu apibrěžtas paslaugas, priskirtinas verslininkui. Taip pat teismas nusprende išsiaiškinti, ar advokato teikiamos paslaugos patenka ị $1993 \mathrm{~m}$. balandžio 5 d. Europos Bendrijų Tarybos direktyvos 93/13/EEB dèl nesąžiningų sąlygų vartojimo sutartyse reglamentavimo sritį, ir jeigu taip - kokiais kriterijais turètų būti vadovaujamasi tokias sutartis kvalifikuojant. Antra, paskutiniai Advokatūros įstatymo pakeitimai sukūre ịstatymo prielaidas panaikinti advokatų reklamos draudimą, ir viešai skelbiama informacija, kad Advokatų taryba baigia parengti Advokatų veiklos reklamos naudojimo reikalavimus ir kontrolès tvarką, kurią jau numatyta derinti su Teisingumo ministerija. Trečia, 2013 m. gruodžio 6 d. nutartimi civilinèje byloje Nr. 3K-3-642/2013 Lietuvos Aukščiausiasis Teismas suformulavo ginčo išsprendimo taisyklę, kad iš anksto sèkmès mokesčio forma sutartas advokato atlygis, atejjus laikui ji advokatui susimokèti, vèliau gali būti teismo ženkliai sumažintas ,atsižvelgiant ị Advokatūros įstatyme nustatytus kriterijus, tik ne ị teisingumo, protingumo ir sąžiningumo principus" (galbūt taip pat galime ịžvelgti vartojimo sutarčių požymių?).

Tebegalioja Advokatūros įstatymo 4 straipsnio 3 dalyje įtvirtintos nuostatos: Advokato veikla yra teisiniu paslaugu teikimas. Advokato veikla néra komerciné ükiné. Būtent dèl to, kad advokato veikla nèra komercinè ūkinè, kad advokatas nèra tiesiog pelno siekiantis asmuo, advokatui buvo draudžiama reklamuotis - kaip skausmingai advokatai ir advokatų bendruomenè reaguodavo ị reklamas „Tik pas mus pigiausios skyrybos“, sakydami, kad tai yra primityvi pelno siekiančių asmenų reklama. Reklamos panaikinimas, o ir Lietuvos Aukščiausiojo Teismo kreipimasis užminè mįslę - atsakymas ị ją bus svarbus tiek advokatams, organizuojantiems savo profesinę veiklą, tiek ir visiems jų klientams. Pagal šios situacijos išsprendimą advokato paslaugų teikimo praktika gali keistis ir jos reglamentavimo, ir jos organizavimo aspektu. Jeigu būtų pripažinta, kad 
advokatas veikia kaip verslininkas, o jo klientas - fizinis asmuo - yra vartotojas, kurio teisės ginamos aktyviau negu ịprastais atvejais, stipriai išaugtų teismo vaidmuo, vertinant advokato paslaugų kokybę. Toks pasikeitęs požiūris galètų sumažinti advokato paslaugų prieinamumą - dèl labai paprastos priežasties. Nereikia būti aiškiaregiu, kad prognozuotum, jog advokatas, prilygintas verslininkui, retai sutiks pradėti teikti paslaugas, negavęs avansinio mokèjimo „ị priekị“. Taip pat tikètina, kad advokatų sutartys su klientais pasidarys itin smulkaus reglamentavimo ir sudètingesnès, su daugybe išlygu ir kliento pareiškimų bei patvirtinimų. Šiandien advokatai labai retai kada ryžtasi bylinètis su klientu dèl nesumokèto atlyginimo už paslaugas, tačiau santykiui pasikeitus verslo santykị, tokios situacijos turètų tapti daug dažnesnès - nes advokatas bylinètųsi tiesiog kaip verslininkas. Turètų atsirasti ir prielaidos advokatų tarpusavio santykio pokyčiams - advokatų klientai turètų samdys kitus advokatus, kad šie jų vardu bylinėtųsi su pirmaisiais dèl netinamų teisinių paslaugų suteikimo ir pan. Tačiau šios publikacijos požiūriu yra ịdomesnis kitas aspektas - kaip keistųsi advokato etikos reikalavimų vertinimas, jeigu būtų pripažinta, kad advokatas veikia kaip verslininkas? Juk jeigu vis dèlto būtų pripažinta, kad advokatas veikia kaip verslininkas, turètų būti susitarta ir dèl to, ar taip veikianti advokatą tokia pačia apimtimi saisto ir etikos reikalavimai.

Jeigu advokatas vis dèlto bus vertinamas kaip bendrojo gèrio gynejas ir teisingumo ịgyvendinimo dalyvis ir jeigu advokatai norès, kad valstybès kišimasis i jų veiklą būtų kiek ịmanoma mažesnis, pati advokatų bendruomenè turès prisiimti iššūkius, kurie kyla advokatams, veikiantiems aštrios konkurencijos, nepalankaus kultūrinio vertinimo ir besikeičiančio reguliavimo sąlygomis, ir pradèti formuoti bei viešai reikšti savo poziciją visais advokato veikloje kylančiais moralinès dimensijos klausimais. O jei advokato veikla jam teikiant teisinę pagalbą bus pradèta laikyti ūkine komercine veikla, jei advokatas bus prilygintas verslininkui (tiesiogiai arba netiesiogiai, pvz., teismams nustatinëjant advokato suteiktų paslaugų tikrają vertę), jei advokato ir kliento sutartims bus pradètos taikyti vartojimo sutarčiu vertinimo taisyklès - galètume liautis kalbèti apie išskirtinai griežtus, etikos reikalavimus atitinkančius elgesio standartus, taikytinus advokatui. Nes verslo, net ir gero verslo, taisyklès nuo advokatui iki šiol keltų reikalavimų skiriasi iš esmès.

\section{Išvados}

1. Advokato profesijai būdingas vidinis prieštaringumas. Advokato veikloje turi būti suderintos trys vertybès: advokato interesas, reiškiantis advokato suinteresuotumą užsiimti šia teisine profesija ir užsidirbti iš to pajamų sau, savo šeimai, savo veiklai; interesas advokato kliento, kurio naudai veikti advokatas ịsipareigoja vos ne besąlygiškai; ir viešas interesas, suprantamas kaip advokato įsipareigojimas tinkamai elgtis teisingumo įgyvendinimo procese.

2. Dèl prieštaringos advokato profesijos prigimties dažnai yra sudètinga suderinti įsipareigojimą besąlygiškai veikti kliento naudai su įsipareigojimu veikti kaip teisingumo įgyvendinimo proceso dalyviui, nulemiančiu griežtesnius padorumo ir elgesio reikalavimus. Todèl būtina sukurti efektyviai veikiančias advokato elgesio kontrolès sistemas. 
3. Valstybė advokato profesiją kontroliuoja mažiausiai iš visų valstybès kontroliuojamų teisinių profesijų. Todèl ypatingą svarbą ịgja advokatų profesinio susivienijimo (Lietuvos advokatūros) vykdoma advokatų elgesio priežiūra ir kontrolè. Lietuvos advokatūra turètų būti suformulavusi ir išsakiusi aiškią nuomonę dẻl advokatų elgesiui taikomų reikalavimų - ne tik teisès, bet ir bendražmogiškos ir profesinès etikos sirtyse. Galima teigti, kad šiuo metu Lietuvos advokatūra aiškios pozicijos dẻl advokatų elgesio vertinimo etikos požiūriu neturi. Jeigu advokatų profesinė bendruomenė nesugebès susikurti skaidrios, nuspejjamos ir nuoseklios vidinès kontrolès sistemos, tai gali būti griežtesnio valstybės advokatų veiklos reguliavimo prielaida.

\section{Literatūra}

Abromavičius, A., et al. Lietuvos teisinès institucijos. Vilnius: Vİ Registrų centras, 2011.

Advokatų etikos dèsniai pagal Advokatų tarybos ir Vyriausiojo tribunolo nutarimus (parengè E. Rusinas). Lietuvos advokatūra. 2011, 4.

Advokatų tarybos veiklos ataskaita. $2012 \mathrm{~m}$. balandžio $20 \mathrm{~d}$. $-2013 \mathrm{~m}$. balandžio $12 \mathrm{~d}$. Balnienè, E. Advokatūros atsiradimas ir raida Lietuvoje. Daktaro disertacija. Socialiniai mokslai, teisè (01S). Vilnius: Vilniaus universiteto Teisès fakultetas, 2007.

Bitinas, A. Advokatūros vieta valstybeje: nepriklausomumo ir autonomijos užtikrinimas. Jurisprudencija. 2012, 77.

Drakšas, R. Advokatas: veiklos pagrindai ir problemos. Monografija. Vilnius: Justitia, 2012.

Dziegoraitis, A. Dar kartą apie teisinę kultūrą ir advokato etiką. Lietuvos advokatūra. 2001, 1.

Krolienè, I. Teisinès pagalbos kokybės vertinimo kriterijai. Lietuvos advokatūra. 2011, 1-2.

Krolienė I. Teisinès pagalbos kokybės vertinimo kriterijai. Lietuvos advokatūra. 2011, 3.

Lietuvos Respublikos advokatūros ịstatymas. Valstybès žinios. 2004, Nr. 50-1632.

Lietuvos Respublikos Konstitucija. Valstybès žinios. 1992, Nr. 33-1014.

Lietuvos Respublikos Konstitucinio Teismo 2008 m. sausio 7 d. nutarimas „Dèl Lietuvos
Respublikos antstoliu ịstatymo 45 straipsnio 3, 5 dalių atitikties Lietuvos Respublikos Konstitucijai“. Valstybès žinios. 2008, Nr. 4-136.

Lietuvos Respublikos Konstitucinis Teismo 2010 m. kovo 22 d. nutarimas „Dėl Lietuvos Respublikos notariato įstatymo 23 straipsnio 3 dalies (2003 m. sausio $23 \mathrm{~d}$. redakcija) atitikties Lietuvos Respublikos Konstitucijai“. Valstybès žinios. 2010, Nr. 34-1620.

Lietuvos Respublikos teisingumo ministro 1999 m. spalio 1 d. įsakymas „Dèl Lietuvos advokatūros statuto patvirtinimo“. Valstybès žinios. 1999, Nr. 95-2753.

Lietuvos Respublikos teisingumo ministro 2005 m. spalio 27 d. ịsakymas „Dèl Lietuvos advokatų etikos kodekso skelbimo“. Valstybès žinios. 2005, Nr. 130-4681.

Lietuvos Respublikos teisingumo ministro įsakymas 2006 m. birželio 21 d. „Dèl advokatų drausmès bylų nagrinèjimo tvarkos skelbimo“. Valstybès žinios. 2006, Nr. 74-2835.

Lietuvos Respublikos teisingumo ministro 2007 m. liepos 11 d. ịsakymas „Dèl advokatų drausmès bylų nagrinèjimo tvarkos aprašo skelbimo“. Valstybès žinios. 2007, Nr. 79-3197.

Tokaczyk, R. Etyka prawnicza. Warsszawa, 2007.

Zajadło, J., et. al. Fascynujące ścieżki filozofii prawa. Warsszawa, 2008. 
Anotacija. Straipsnyje analizuojama advokato kaip vienos is valstybès kontroliuojamu teisiniu profesiju statusas. Atkreipiamas demesys, kad advokato profesija yra prieštaringa: viena, advokatas iš savo profesijos užsidirba pajamu sau, savo šeimai ir savo veiklai; antra, advokatas yra ipareigotas besalygiškai siekti, kad jo kliento interesas bütu patenkintas kuo didesne apimtimi; trečia, advokatas yra vienas is teisingumo igyvendinimo dalyviu, kuriam taikomi aukštesni elgesio standartai, dažniausiai siejami ne tik su formaliais teisiniais, bet ir su etikos reikalavimais. Šis advokato veiklos prieštaringumas suponuoja bütinybę, kad advokato veikla bütu kontroliuojama išorinemis priemonemis. Nurodyta problema turetu büti analizuojama doktrininiu lygiu, ko Lietuvoje pasigendama.

Reikšminiai žodžiai: valstybès kontroliuojama teisinè profesija, advokatas, Lietuvos advokatūra, Advokatu etikos kodeksas, teisingumo igyvendinimas.

\section{ATTORNEYSHIP: ITS CONTRADICTORY NATURE AND CONTROL}

\section{Giedrè Lastauskienè}

Vilnius University, Lithuania

Summary. This paper analyzes the status of attorneyship as one of the state-controlled legal professions. It should be noted that although the public recognizes the importance of lawyer's assistance, in the cultural context lawyer is one of the most ridiculed and criticized legal professions. Such assessment of attorneyship depends on the controversial nature of this legal profession, i.e. first, the lawyer uses his profession to earn income for himself, his family and his business; second, the lawyer is obliged to unconditionally pursue his client's interests to a widest extent possible; and third, the lawyer is one of those participating in the justice implementation and, as a result, is the subject to higher standards of behaviour, normally associated with both formal legal requirements and ethical requirements. The lawyer's personal interest is mostly in line with his commitment to act exclusively for the benefit of the client, because protection of the client's interests determines the lawyer's reputation and income. However, obligations of the lawyer, as the justice implementation participant, often force the lawyer to act otherwise than they would normally act in order to benefit their client. At this date, the controversial nature of attorneyship in Lithuania has yet not reached the level of doctrinal debate; therefore, it is difficult to assess what theoretical models could be considered appropriate when solving this problem.

Such divergence leads to the demand that attorneyship would be controlled by external means. The general external control over attorneyship may be exercised by both lawyers' professional association (the judicial control over attorneyship in a particular case is not addressed in this article). The paper provides points proving that attorneyship is Lithuania's least state-controlled profession as compared to other similar professions, e.g. bailiff or notary. The Lithuanian Bar Association bears the primary responsibility for lawyers' ethical performance. After assessing the published data on the Lithuanian Bar Association activities, 
it can be stated that the control provided is insufficient, often identifying and responding to formal violations, such as non-payment of contributions and failure to submit the public liability insurance policy. There is no evidence that the Lithuanian Bar Association has a clear position concerning the lawyers' ethics and expresses it in such a way that no lawyer could question assessment of behaviour non-compliant with ethical principles.

Even more questions arise in the light of the latest trends. The Supreme Court of the Republic of Lithuania asked the European Court of Justice for a preliminary ruling in determining whether in certain cases the lawyer, providing legal services to an individual, should be recognized as a business person, his client as a consumer, and the legal aid contract as a consumer contract. At the same time, a legal prerequisite for the lawyer advertising has been created in Lithuania, which had been strictly probibited until recently. There are grounds for believing that the lawyer will be viewed more as a business person than as a person involved in the justice implementation process. As a result, the extent of ethical requirements to the lawyer may change.

Keywords: state-controlled legal profession, lawyer, Lithuanian Bar Association, Bar Code of Conduct, justice implementation.

Giedrè Lastauskienė, Vilniaus universiteto Teisès fakulteto Viešosios teisès katedros docentè. Mokslinių tyrimų kryptis: teisès teorija.

Giedrė Lastauskienè, Vilnius University, Faculty of Law, Department of Public Law, Associate Professor. Research interest: Theory of Law. 